\title{
Necati Cumalı'nın Oyunlarında Mekân ve Coğrafyanın Kurgulanışı: Kent ve Kasaba İmgesi
}

\author{
Arş. Gör. Dr. Tuğba ÖZKAN \\ İstanbul Arel Üniversitesi \\ Fen Edebiyat Fakültesi, Türk Dili ve Edebiyatı Bölümü \\ tugbaozkan@arel.edu.tr \\ ORCID: 0000-0001-8460-1580
}

\begin{abstract}
Öz
Necati Cumalı'nın oyunlarına odaklanan bu çalışmada, yazarın eserlerindeki mekân ve coğrafyanın kurgulanması üzerinde durulmaktadır. Çalışmanın teorik çerçevesinde mekân kavramı hakkındaki düşünsel arka plana ve kavramsal yapıya değinilmekte ve edebiyat bilimi içindeki mekân araştırmalarının seyrine yer verilmektedir. Bunun yanı sıra jeosantrik edebiyat araştırmalarının amacı, yöntemi ve gelişimi üzerinde genel hatlarıyla durulmaktadır. Yazarın eserlerindeki mekân ve coğrafya seçimleri sorgulanarak kent ve taşraya dair görünümler saptanmakta ve değerlendirilmektedir. Oyunlarda yer alan mekân ve coğrafyaya ait edebî temsillerin daha çok istanbul, Ankara, İzmir gibi büyük kentler ile başta Ege kasabaları olmak üzere Anadolu taşrası olduğu dikkat çekmektedir. Bu doğrultuda çalışmanın bölümlendirilmesi de Cumalı oyunlarında köy ve kasaba imgesi etrafında taşranın temsili ile kent ve küçük insanın gündelik dertleri şeklinde yapılmaktadır. Ayrıca kasaba ve köy temsillerinin dram ve komedi türleri içinde farklı şekillendirilmesi ve meselelere farklı tonda veya farklı cephelerden yaklaşılması nedeniyle bu türler de kendi içinde gruplandırımaktadır. Biyografik unsurların yazarın eserlerindeki mekân seçimi ve mekânın temsilin de etkili olduğu görülmektedir. Yazarın hayat coğrafyasıyla kesişecek şekilde Ege coğrafyası oyunlarda sıkıkla edebî mekân olarak kurgulanmaktadır.
\end{abstract}

Anahtar Kelimeler: edebiyat coğrafyası, jeokritik, edebiyatta mekân çalışmaları, cumhuriyet dönemi tiyatrosu, edebiyatta ege bölgesi, edebiyat ve kent.

Özkan, T. (2021). Necati Cumalı'nın Oyunlarında Mekân ve Coğrafyanın Kurgulanışı: Kent ve Kasaba İmgesi. ARTS: Artuklu Sanat ve Beşeri Bilimler Dergisi, Necati Cumalı Özel Sayısı, ss. 44-73. 


\title{
Fictionalizing Space and Geography in the Necati Cumali's Plays: Images of City and Small Town
}

\begin{abstract}
This study, which focuses on Necati Cumali's plays, deals with the fictionalization of space and geography in the author's works. Theoretical framework of the study includes the intellectual background and conceptual structure of the concept of space, and the course of space studies in literature. In addition, it discusses the aim, method and development of geocentric literature studies in general terms. The study determines and evaluates the views of the urban and the rural by questioning the choices of place and geography in the author's works. It has been noticed that the literary representations of the space and geography in the plays are mostly the bigger cities such as Istanbul, Ankara, Izmir and the Anatolian provinces, especially the Aegean small towns. Accordingly, the study has been divided into sections based on the representation of the provinces around the image of the village and small town, and the city and everyday problems of the ordinary people in Cumalı's plays. In addition, as the representations of towns and villages are shaped differently in drama and comedy genres, and the issues are approached in different tones or from different aspects, the sections are also subgrouped based on these genres. The study indicates that biographical elements are effective in the processes of choosing places and their representation in the works of the author. Aegean geography is often fictionalized as a literary space in the author's plays, intersecting with his own life geography.
\end{abstract}

Keywords: literary geography, geocritisicm, spatial literary studies, republican theatre, necati cumall, aegean region in literature, literature and city. 


\section{arts}

\section{Gíriş}

Anlatının en önemli unsurlarından olan mekânın ve edebî eserlerde konu edilen coğrafyanın araştıııması, bu mekân ve coğrafyanın kurgulanışında öne çıkan yönlerin saptanması, yazarının mekân ve coğrafya tercihlerinin sorgulanması, coğrafyanın ve mekânın temsil değerinin ortaya konulması, edebî eserlerle ilgili önemli bir anlam alanı açmaktadır. Necati Cumalı'nın eserlerindeki coğrafya seçiminde birtakım tercihlerin öne çıktığı görülmekte ve yazarın hayat coğrafyası ile eserlerinin coğrafyası ve mekânları arasında birtakım kesişimler saptanmaktadır. Roman ve hikâyelerinde Ege coğrafyasını öne çıkaran veya Balkan kültür ve coğrafyasına has unsurları eserlerine yansıtan Cumall, kendisini ait hissettiği ve yetiştiği kültür ve coğrafyalarla eseri vasıtasılyla temasta bulunmaktadır. Bu noktada yazarın içinden çıktığı veya yetiştiği coğrafyaya eserleri vasıtasılyla sunduğu hizmeti ve faydayı sorgulamak da mümkün olmaktadır. Bunları göz önünde bulundurarak edebî eserler bağlamında gerçekleştirilen mekân ve coğrafya araşsırmalarının farkı cephelerine bakmak gerekmektedir.

Coğrafya merkezli edebiyat araştırmalarının başlangıcı, yirmi birinci yüzylın illk yarııına tarihlenirken mekân ve coğrafya hakkındaki düşünsel birikim çok daha eski tarihlere dayanmaktadır. Farklı disiplinlerin bünyesinde mekân üzerinden üretilen yeni teorilerin ve felsefi yaklaşımların edebiyat araşıırmalarını etkileyip zenginleştirdiği bir gerçektir. Özellikle 1960'lardan itibaren spatial turn isimli fikir hareketi kapsamında geliştirilen mekânla ilgili görüşler tüm sosyal bilimler sahasında belirginlik kazandığı gibi edebiyat araş̧ırmalarında da hatıı saylır bir yer edinmiştir (Tally, 2017, s. 11 12). Aristo'nun topos ve Platon'un khora kavramına getirdiği açllımlardan itibaren mekân kavramı hakkında ortaya sunulan görüşler ve kavramlar edebî eserin anlamlandırıması sürecine kaynaklık etmiştir. Mekân ve yer kavramları ile ilgili düşünsel birikime ve alanın terminolojisine yapılan katkılar arasında David Harvey'in urban space (kentsel mekân); Michel Foucault'nun heterotopia; Henri Lefebvre'nin lived space (yaşanan mekân), social space (toplumsal mekân) ve conceived space (tasarlanmış mekân); Marc Augé'nin non-places (yer-olmayanlar); Edward W. Soja'nın thirdplaces; Yi-Fu Tuan'ın topophlia (Çam, 2016, s. 11) örneklerinde görülen kavramlar öne çıkmaktadır. 
Bollnow'un derinleştirdiği deneyimlenmiş mekân ve fizikî mekân karşıtlı̆ı fikrinden hareket eden ve deneyimlenmiş mekânın özel bir biçimi olarak ortaya çıkan hodolojik mekân kavramı hodos (patika) ve logos kelimelerinin birleşmesinden oluşmaktadır. Hodolojik mekân, yollar ve izleklerle örülmüş; yolların ve izlenimlerin iç içe geçtiği bir yapı arz eder. Gilles Deleuze, Kritik ve Klinik adlı eserinde Freud'dan mülhem öznenin mekânla ilgili izlenimlerine dayanan görüşlerini geliştirmiştir (Çam, 2018, s. 47-48). Bunun yanında deterritorialization (yersizyurtsuzlaştırma) ve göç olgusu üzerine görüşlerini sunan Deleuze, bu kavramlar etrafında mekân felsefesine getirdiği açılımlarla alana mühim katkılar sunmuştur. Dylan Trigg de topophobia kavramını anksiyetenin fenomenolojisi hakkındaki araştırmasında ortaya koymuştur. Edebiyat eleştirmeni ve araştırmacı Robert T. Tally Jr., Topophrenia: Place, Narrative and the Spatial Imagination (2018) eserinde kişinin yerle ilgili deneyimlerine ve öznel bağına gönderme yapan topophrenia kavramını geliştirir. Bakhtin, edebiyat eleştirisi sahasında yaygınlaşmış bir kavram olarak anlatıda zaman ve mekânı birlikte değerlendiren chronotope kavramını "Forms of Time and of the Chronotope in the Novel" (1937-38) yazısında ortaya koymuştur. Gaston Bachelard, Mekânın Poetikası (1957) eserinde, edebî metin içindeki evin ve insanın varlığının karışmasıyla ilgili imgelere temas ederek mekân konusuna farklı bir açılım getirmiştir (Uğurcan, 2012, s. 246).

Toplumların mekân aracılığıyla incelenmesini sağlayan (Kefeli, 2006, s. 7) coğrafya bilimi, özellikle beşerî coğrafya alanı, insan hayatını çeşitli cepheleriyle anlamak için mühim bir vasıtadır. Coğrafya, "insanların duygu ve düşüncelerinin şekillenmesinde önemli bir rol oynar. İnsanlar yetiştikleri coğrafyanın yüzey şekilleri, bitki örtüsü iklim koşullarına bağlı olarak bazı fizikî ve ruhî özellikler kazanırlar. İnsan hayatının yeniden kurgulandığı edebî eser de kendisini yaratan coğrafyadan izler taşır. Bu nedenle dünyadaki en az gelişmiş bir edebiyat örneğinde dahi içinde doğup büyüdüğü coğrafyanın damgası vardır." (Kefeli, 2006, s. 7). Coğrafyanın insanların yaşam koşullarını, fizyolojik ve psikolojik özelliklerini şekillendirdiğini belirten Kefeli, coğrafya biliminin edebî eserin anlamlandırıması ve yorumlanması sürecinde önemli bir disiplin olduğuna vurgu yapmaktadır. Mehmet Kaplan da edebiyat coğrafyasından bahsederken Halide Edip'in Ingiliz Edebiyatı Tarihi (1940) eserinde öne sürdüğü görüşlerini bu bağlamda vurgulamaktadır. Halide Edip, iklim ve tabiatın milletleri şekillendirdiğini belirterek büyük veya küçük dünya edebiyatının tümünde 


\section{arts}

doğup geliştiği yerin damgası bulunduğunu belirtmiştir (Kaplan, 2014, s. 148).

Edebiyat sosyolojisinin kurucusu sayılabilecek Madame de Staël, coğrafya ve geniş manasıyla iklimin edebiyat üzerinde etkili olduğuna vurgu yapan isimlerden biridir. Almanya Üzerine (1813) ve Edebiyata Dair (1799) isimleriyle Türkçeye tercüme edilen eserlerinde iklimin edebiyatlar üzerinde etkili olduğuna vurgu yaparak kuzey ve güney edebiyatlarının farkını buna bağlamaktadır. Hippolyte Taine, "ırk-zamanyer" veya "Irk-an-muhit" olarak tercüme edilen edebî nazariyesinde bu üç unsurun edebî eseri şekillendirdiğini ve eserlerde belli coğrafyaların karakteristik özellikleriyle yer aldıklarını; bu üç unsura göre edebiyatların değişiklik gösterdiğini belirtmekte, ırk ve yer konusuna temasıyla edebiyatı coğrafyayla ilişkilendirmektedir (Kefeli, 2006, s. 15). Montesquieu de Iran Mektupları (1721) ve Kanunların Ruhu Üzerine (1748) eserlerinde iklim ve coğrafyanın toplumları anlamak için önemli olduğunu, kültür ve medeniyet üzerindeki etkisini vurgulamaktadır (Aslan Cobutoğlu, 2014, s. 73).

Edebiyat-coğrafya ilişkisi, edebiyat coğrafyası (Kefeli, 2006, s. 14), coğrafya merkezli okuma (Kefeli, 2009, s. 423) başlıkları altında değerlendirilen edebî eserin coğrafyası üzerine odaklanan araştırmalar, ülkemizde son dönemlere tarihlenmektedir. Buna karşılık edebî eserin mekânı üzerine yapılan araştırmalar, daha erken örneklerdir. Edebiyat coğrafyası üzerine ülkemizde ilk adı anılan eser, André Ferré'nin La Géographie Littéraire (1946) kitabıdır. Mehmet Kaplan "Edebiyat Coğrafyası" başlıklı makalesinde Ferré'nin bu eserini anarak edebiyat coğrafyasının müstakil bir ilim mevzuu olduğu konusuna temas eder (Kaplan, 2014, s. 149). Yine Kefeli, Ferré'nin géo-littéraire yaklaşımın başlı başına bir araştırma alanı olarak belirmesine olan katkısına işaret eder. Ferré'ye göre, metnin dokusundaki gerçek veya kurmaca mekânlara ait tasvirler, metnin coğrafi içeriği, yazarın hayat coğrafyası ve coğrafi deneyimleri edebî metnin anlamlandıııması sürecinde araştırmacılara yeni bakış açıları sunmaktadır (Kefeli, 2006, s. 16). Ferré'den sonra Salter ve Lloyd, Westphal, Tally Jr., Pocock, Pieto, Brosseau başta olmak üzere birçok isim, coğrafya merkezli edebiyat araştırmalarını yürüterek alanın müstakil bir disiplin olarak gelişmesine katkı sağlamış ve geocriticism' in kavramsal yapısını şekillendirmişlerdir. Pocock, 1981 tarihli "Place and the Novelist" başlıklı makalesinde edebî metinler, coğrafyacıya kaynak olabilir mi sorusuna yanıt niteliğindeki görüşlerini sunar. Coğrafya araştırmacısının temel çalışma alanı olan insan-çevre ilişkisini açıklamak noktasında edebiyatın 
yaratıcı özellikleriyle çok önemli bir kaynak olduğunu belirtmektedir (Pocock, 1981, s. 345).

Brosseau, (2019, s. 215) coğrafyanın edebiyata olan yaklaşımının 1960'larda bölgesel, 1970'lerde humanistik, 1980'lerde radikal ve materyalist, 1990 ve 2000'lerdeyse yeni kültürel coğrafya cephesinden gerçekleştiğini belirterek genel bir çerçeve çizer. 60'lar 70'ler, 80'ler boyunca on dokuzuncu yüzyılın realist ve bölgesel edebiyatına ait türlere odaklanan jeosantrik yaklaşım, 90'larda modernist, çağdaş, bilim kurgu, suç ve kara anlatı türlerine eğilir. 2000'lerde ise kolonyal ve postkolonyal veya Batılı olmayan edebiyat ürünlerine, çocuk edebiyatı ve fantezi edebiyat türlerine hâkim edebî türler olarak yaklaşır. 1970'lere gelene dek coğrafyacılar edebiyat ile sürekli bir etkileşim hâlinde bulunmasa da, bu tarihe kadar yazılan bir dizi eser veya makale coğrafya disiplininin edebiyata olan ilgisini çeşitli cepheleriyle ortaya koymaktadır. Buna rağmen coğrafyacıların edebiyata karşı ilgileri 1970'lere kadar marjinal kalmıştır (Brosseau, 1994, s. 334). 1970'lerden itibaren bu kapsamda romancının, iyi bir coğrafyacı olup olmadığı; bölgesel monografilere veya coğrafya alanında yazıımış eserlere bağlı kalıp kalmadıkları sorgulanır. Bölgesel coğrafyacıların bu edebî sorgulamalarındaki amaç, edebiyatın belgesel değerini, özellikle bölgesel farklııkları yetkin bir şekilde sunan on dokuzuncu yüzyılın realist romanları çerçevesinde (Brosseau, 2019, s. 212) belirtmektir.

Coğrafya merkezli edebiyat incelemelerinde metinler üzerindeki bazı hususlardan hareket edilmektedir. Bunların başta geleni metinde yer alan kurmaca veya gerçek mekânların tasviridir (Kefeli, 2009, s. 430). Bununla ilgili olarak edebî eserlerdeki coğrafi görünümlerin, manzara tasvirlerinin üzerine eğilen birçok isim vardır. Bunlar arasında Salter\&Llyod, 1977 tarihli Landscapes in Literature eseriyle öne çıkmaktadır. Metnin iklim, bitki örtüsü, topoğrafik yapı gibi coğrafi içeriğinin incelenmesi, seçilen veya yaşanan coğrafyanın eser bağlamında değerlendirilmesi, yazarın hayat coğrafyası ve coğrafi deneyimleri de (Kefeli, 2009, s. 431) coğrafya merkezli edebiyat incelemelerinin üzerinde durduğu konulardır. Korat da doğa ve coğrafyanın edebiyatla yazı nesnesini koşullamak noktasından ilişkili olduğunu belirterek yazarların doğayı ele alış biçimleri bakımından üç farklı eğilim gösterdiğini belirtir: "Birincisi doğayı ve edebiyatı iç içe geçirerek anlatanlar, ikincisi doğayı bir fon olarak kullananlar, üçüncüsü doğayı değil de doğanın bir parçasını, mekânı 


\section{arts}

edebiyata indirgeyenlerdir." (Korat, 2005, s. 52).

Bazı edebî türler, pastoral şiir, seyahat ve gezi anlatıları, ütopyalar, kent romanları veya yer isimleriyle adlandırılan çeşitli edebî eserler, mekân ve coğrafyaya dair özelliklerin öne çıkarılmasıyla bu hususta karakteristik bir yapıya sahiptirler. Bunun dışında "regional novel" olarak adlandırımış edebî tür de bölgesel olana odaklanan yapısıyla edebiyat coğrafyası araştırmalarının önemli bir alanını teşkil etmektedir. Ayrıca edebiyat araştırmalarında Ege, Akdeniz, Karadeniz vd. örneklerle edebî esere yansıyan mikro coğrafyaların da konu edildiği ve bu sahada çalışmaların yürütüldüğü görülmektedir. Edebî eserdeki bölgesele odaklanan bu çalışmalar da edebiyat coğrafyasının içinde özel bir yere sahiptir. Ege coğrafyasına odaklanan eserleriyle Halikarnas Balıkçısı, Necati Cumalı yanında Güney Anadolu'yu Çukurova Özelinde eserlerine taşıyan Orhan Kemal ve Yaşar Kemal başta olmak üzere birçok ismin bölgesel edebiyata katkı sağladıkları görülmektedir. Korat'ın belirttiği gibi belli şehirleri veya coğrafi bölgeleri merkeze koyan, kahramanlarını bu doğrultuda hareket ettiren yazarlar, o coğrafyanın yazarı olarak anılabilirler. Coğrafya yazarın duygu, düşünme ve algılama eşiğini oluşturduğu için yazarın eserinin coğrafya, yerel dil, insan tipleri gibi birçok yerel unsurdan bağımsız olması düşünülemez (Korat, 2005, s. 55). Jeosantrik edebiyat araştırmalarından öne çıkan meselelerden biri de mekânın gerçek veya kurgusal olması ekseninde gelişir. Gerçek yerlerin kurgulanması yanında birçok yazar eserinde, kurmaca mekânlar üreterek kurmaca ile gerçeklik arasındaki ilişkiye mekânsal planda bir açılım getirmektedir.

Edebiyat ve coğrafya ilişkisinin bir başka boyutu, kenti veya köyü konu edinen eserlerde ortaya çıkmaktadır. Köy romanı gibi bir roman türünün gelişmiş olması yanında kenti çeşitli cephelerle ele alan ve kent kavramını öne çıkaran romanlar, edebiyat tarihlerinde yer bulmaktadır. Dublin-Joyce, Prag-Kafka, LondraDickens örneklerinde beliren bir yazarın bir kentle özdeşleştirilmesi de edebiyat ve kent araştırmalarında öne çıkan bir konudur. Edebî eserdeki kent temsilleri, özellikle yazarın o kenti hangi bağlamlarda değerlendirdiğini, kent hakkındaki algılarını ve kente dair zihnindeki imgeleri yansıtması açısından araştırma konusu olmaktadır. Kentin edebî eser vasıtasıyla haritasının çıkarılması hakkında yürütülen çalışmalar, bu kapsamda jeokritik ile birlikte gelişen kartografik edebiyat çalışmalarının da gelişmesine imkân yaratmıştır. Bunun dışında edebî haritalarla belirtilmesi mümkün 
olan, edebî eserlere yansıyan semtler ve mahalleler de edebiyat coğrafyasının ilgi alanı olmaktadır. Özellikle İstanbul semtlerinin Türk edebiyatında temsili hakkında semtler özelinde yapılacak çalışmalar şiir, roman ve öykü sahasında yapılmış tek bir yazara ait monografik İstanbul temsilleri hakkındaki araştırmalara ek olarak bu sahada daha geniş katkılar sunacaktır.

Edebî eserin mekânı hakkında yapılan araştırmalar daha çok eserin geçtiği yeri iç ve dış, kamusal veya özel alan bağlamında değerlendirilirken daha ziyade ev içine veya diğer özel alanlara odaklanan eserlerde mekân, karakterin psikolojisiyle bağdaştııımaktadır. Buna karşlık kamusal alana veya daha geniş planda coğrafyaya veya idari birer birim olan şehir, köy ve kasabaya odaklanan eserin daha genel bir atmosfer sunduğu görülmektedir. Bu yüzden eserlerdeki kent ve kasaba imgesine bakacak olursak daha dar planda sunulan mekânın aksine daha genel yargılar ve kültürel kodlar sunabileceğini ve temsil gücünün öne çıkarılacağını görebiliriz. Kent ve taşra karşıtlığı, kasabanın yazgısı olarak sunulan taşranın kenarda kalmışlığı veya kent hayatı içinde sunulan karmaşık yaşam örüntüleri kent ve kasaba imgesi bağlamında sunulan belli başlı görüntüler arasındadır.

Köy ve kentin çeşitli boyutlarıyla edebî eserde temsil edilmesi yaygınlık kazanmışken kasaba temsillerinin çok daha geri planda kaldığı görülmektedir. Kasaba, kent ve köy arasında konumlandırılan; hem şehre benzemeye çalışan hem de kırsal özelliklerini devam ettiren; gelenek ve yenilik arasında salınan; üretim ve tüketim biçimleri dâhil hemen her konuda gelenek ve yenilik sentezini bir arada barındıran bir yapıya sahiptir (Kavaz, 2018, s. 147). Bu anlamda Türk edebiyatındaki kasaba temsillerinin değerlendirilmesi önem kazanmaktadır. Kent ve kasabanın temsil ettiği değerlerin ve kültür kodlarının farklılığı da coğrafyaya atfedilen bir durum olarak görünmektedir. Coğrafya ve mekân farklı bileşenleriyle kent veya kasaba insanına ve onun hayat görüşüne, yaşam tarzına etki etmekte ve bu etki de edebî eserdeki temsili bağlamında sorgulanabilmektedir.

Kentli insanın veya taşrada, kasabada yaşayan insanın içinde bulunduğu maddi koşullar, iktisadi eylemleri, değer yargıları, arzuları ve eylemlerini yöneten diğer etkenler fiziki çevreye ve coğrafyaya atfedilen değerler olarak görülebilmektedir. Bu anlamda bir eserin coğrafyasına odaklanırken çok daha geniş bir cepheden 


\section{arts}

yaklaşmak mümkün olacak ve bu cepheler de temelde fizikî coğrafya veya beşerî coğrafya olarak sınıfandıılacak unsurlarla şekillenecektir. Yazarın edebî tercihlerine göre fiziki coğrafyaya has unsurların fazlaca yer bulacağı bir eser yanında daha çok beşerî coğrafya unsurlarının öne çıkması da mümkündür. Özellikle kent ve kasaba bağlamında bakılacak olursa beşerî coğrafyaya ait alanlar olan nüfus hareketleri ve göç, yerleşim birimleri, etnik coğrafya ve kültür coğrafyası gibi alanlara ait unsurların edebî eser içinde çok geniş bir alan bulduğu görülecektir. Fiziki coğrafyaya has iklim ve doğa koşulları gibi ögeler, belki de esere konu olan insanın hayatı çerçevesinde yer bulacaktır.

Edebî metnin coğrafyası ve mekânları üzerine düşünürken yazarın hayał coğrafyasına bakmak, eserdeki mekân seçimleri üzerine düşünmek edebiyat coğrafyasının başlıca konularındandır. Yazarın hayat coğrafyası, esasında coğrafya merkezli bir biyografik çalışmadır. Bu çerçevede yazarın doğup büyüdüğü ve hayatının çeşitli devrelerinin geçtiği coğrafyalar esas alınır. Yazarın hayat coğrafyası, edebiyat coğrafyası araştırmaları yanında karşılaştırmalı edebiyat araştırmalarında tesir meselesi ve beslenme kaynaklarının tespit edilmesine de kaynaklık eder (Kefeli, 2006, s. 16). Edebî eserin mekânı ve coğrafyası hakkında üzerinde durulacak başlıca nokta şu olabilir ki her yazar en iyi bildiği, içinde yaşadığı mekânı ve coğrafyayı büyük bir rahatlıkla anlatır, tasvir eder, orada yaşanılan hayatı hikâyeleştirir. Necati Cumalı'nın edebiyatında da bunu görebiliriz; özellikle kendi hayat coğrafyasında önemli bir yer tutan Urla ve dolayları özelinde Bałı Anadolu bölgesindeki hayatı eserlerinde konu etmektedir.

Necati Cumalı'nın eserlerinin coğrafyası ve mekânları ile hayatındaki önemli mekân ve coğrafyaların kesişim hâlinde olduğu görülecektir. Yazarın biyografisinde Balkan ve Ege coğrafyaları öne çıkmaktadır. Makedonya 1900 (1976) kitabındaki öyküler, Balkan coğrafyasından ve Balkan halklarının yaşamından izler taşımasıyla yazarın Balkanlara dayanan aile kökleriyle ilişkilendirilmektedir. Yazar, "Kaylar Rehberim" adlı öyküsünde annesinin kasabasından bahsettiğini belirtir. Lozan Antlaşması sonrasında gerçekleşen mübadelede memleketleri Florina'dan ayrılmak zorunda kalan Cumalı ailesi, İzmir'in Urla ilçesine yerleşerek burada yaşamaya devam eder. Eserine yansıyan Balkan coğrafyası gibi Cumalı'nın roman, öykü, piyes gibi birçok türdeki eserinde özellikle Urla özelinde Ege coğrafyası geniş yer bulur. 
Ortaokul ve lise eğitimini İzmir şehir merkezinde tamamlayan Cumalı, 1938' de hukuk eğitimi görmek için İstanbul'a gelir. Ancak bir bunalım devresi nedeniyle 1939'da Ankara'ya geçerek hukuk eğitimini orada tamamlar. 1949 yllında İzmir bölgesi milli eğitim başmüfettişliği görevine atanana kadar Ankara'daki memuriyet hayatını sürdürür. 1950-57 arasında İzmir ve Urla'da avukatlık yapar. Sonrasında çeşitli sebeplerle sırasıyla Paris, İstanbul, Tel-Aviv ve tekrar Paris'te yaşayan Cumalı'nın bu mekânsal deneyimleri eserlerinde yer bulacaktır. 1966'da istanbul'a dönerek bundan sonra dünyanın farklı şehirlerine seyahatlerde bulunur (Taş, 2001, s. 3-9).

Balkan ve Ege coğrafyasının eserinde yer bulması yanında bir süre kaldığı Paris şehrini oyunlarına mekân seçmesi, İsrail' de yaşaması dolayısıyla kültürel planda eserlerinde Eski Ahit'te yer alan hikâyelere göndermeler yapması Cumalı'nın mekânla ilgili deneyimlerinin eserlerini etkilediğini gösteren örnekler arasında görülebilecektir. Yine yazarın hayatından yola çıkarak eserlerine bakılırsa görülür ki adli vakalar dolayısıyla avukatlık büroları, avukat karakterlerin bulunduğu çeşitli ortamlar da gözden kaçmayacak şekilde yoğunlukla işlenmektedir. Biyografik okuma yaparak yazarın eserlerine yaklaştığımızda hem eserlerindeki mekân ve coğrafya seçiminde hem de karakter yaratma yönteminde hayatından izler bulunduğunu görmek mümkündür.

Necati Cumalı'nın oyunlarına coğrafyayı veya mekânı merkeze alarak bakacak olursak dikkati çeken unsur, köy ve kasabayla taşranın, taşra hayatının temsil edilmesi yanında kent yaşamından sahnelerin, kentli insana dair meselelerin piyes formunda sunulmasıdır. Bu yüzden yazarın oyunlarını değerlendirirken eserleri taşrayı yani köy ve kasabayı anlatan eserler ile kent hayatını anlatan eserler olarak ikiye ayııı değerlendirmek yerinde olacaktır. Bunun dışında Zorla Ispanyol ve Aşk Duvarı oyunlarının mekânı Paris şehridir, Vatan Diye Diye oyunu Namık Kemal'in hayatı etrafında kurgulanmıştır ve Osmanlı İstanbul'u başta olmak üzere Osmanlı ülkesinin farkı coğrafyalarında geçmektedir. Ayrıca yazarın, "Karalar Ülkesi" adlı, haritada yeri olmayan bir ülkenin küçük bir ilçesinde geçtiği belirtilen Tehlikeli Güvercin oyununun muhayyel bir coğrafyayı mekân edindiği görülmektedir. 


\section{$\operatorname{arts}=$}

\section{KÖY VE KASABA IMGESi: NECATi CUMALI OYUNLARINDA TAŞRANIN TEMSILI}

Türk edebiyatında taşra, çeşitli cepheleriyle temsil edilmiş ve özellikle köy edebiyatının belli bir gelişme kaydettiği görülmüştür. Kasaba birimi üzerinden taşrayı konu eden eserler geri planda kalsa da edebiyat tarihimizde birçok eser taşranın meselelerine eğilmiş ve taşraya ait olanı ekonomik, sosyal, siyasi, boyutlarıyla konu etmiştir. Edebiyat tarihimizdeki örneklerinde gözlemleneceği gibi farklı kadrajlardan taşraya bakan yazar, içerden veya dışardan bir gözle taşraya bakarak taşra problemlerini ve taşra algılarını sergilemiştir (Narlı, 2013, s. 313). Necati Cumalı da, roman ve hikâyelerinde olduğu gibi oyunlarında da köy ve özellikle kasabayı işlemiş ve kendi perspektifinden taşrayı eserlerinde yansıtmıştır.

Cumalı'nın ilk piyesi Boş Beşik' ten (1949) başlayarak sırasıyla Kristof Kolomb'un Yumurtası, Kaynana Ciğeri, Mine, Nalınlar, Derya Gülü, Susuz Yaz, Vur Emri, Ezik Otlar, Gömü ve Bakanı Bekliyoruz isimli oyunlarında köy ve kasaba hayatından manzaralar sunduğunu görmekteyiz. Doğan Hızlan tarafından Gösteri dergisi için yapılmış 1981 tarihli söyleşide Necati Cumalı, kasabanın neden değerli olduğunu şu sözleriyle belirtmektedir: "Kasaba, yani ne kent ne köy, ikisi karışımı bir yerleşim merkezi. Türkiye'yi en iyi yansıtan yerleşme örneğidir bence kasaba. Kasaba kültürü bütün yaşamımızı etkiler. Kasaba görgüsü egemendir bütün değer ölçülerimize. Politika, eğitim, sanat, hoşgörü ortamını kasaba saptar bize." (Hızlan'dan aktaran Taş, 2001, s. 14). Yazarın ortaya koyduğu kasaba imgesiyle bir arada kalmışlığı simgelediğini söylemek mümkündür. Cumalı'nın folklorik bir çerçeveden köy imajı çizdiğini söyleyecek olursak onun eserine yansıyan kasabanın çok daha gerçekçi olduğunu görmek mümkündür. Bu durumu, yazarın kendi hayatında kasabaya ait gözlemlerinin çok daha fazla olduğuna ve bunu eseri vasıtasıyla dile getirmek istediğine bağlamak mümkündür.

\section{Taşranın Yazgısı: Dram Türü İçinde Köy ve Kasaba Hayatının Akisleri}

Mine (1959), kasaba gerçeğini yansıtan en mühim Necati Cumalı oyunu olarak öne çıkmaktadır. Bałı Anadolu'da Gölköy takma adlı kasabanın istasyon binası etrafında kurgulanan piyeste, yazarın kasaba gerçeğini ustalıkla yansıttığını söylemek mümkündür. Kasabanın haritada bulunan gerçek bir kasaba ismiyle adlandırımaması, yazarın kendisinin belirlediği bir takma adı kasabaya vermesi 
dikkat çekici bir unsurdur. Böylece yazar, genel bir Anadolu kasabası atmosferini yansıtmış olacaktır. Bu sebeple bazı unsurları ve ifadeleri eserden çıkarırsak söz gelimi olayların küçük bir Batı Anadolu kasabasında geçtiği, gelen trenin Bandırma-l̇zmir ekspresi olduğu eserde belirtilmese ya da oyun içindeki bazı sahnelerde köylüler Ege şivesiyle konuşturulmasa herhangi bir Anadolu kasabasının söz konusu olduğunu söylemek mümkün görünecektir.

Cumalı, hayali mekân kullanımını, sonradan siyasi bir yergi tonu taşıyan Tehlikeli Güvercin (1967) oyununda daha belirgin şekilde yapacaktır. Yazar, bu muhayyel kentte yaşananları anlatırken kendisine çok daha rahat bir şekilde yaşanan olayları tenkit etme imkânı yaratır. Dile getirilmesi zor olan, cesaret isteyen meselelerin reel düzlemde değil, hayali mekânlarda geçen olaylarla anlatılması tarih boyunca yazarların kullandığı yöntemlerden biri olmuştur. Benzer şekilde Mine'de yazar, olayların Gölköy ismiyle kurgulanan bir kasabada geçtiğinin notunu düşmüştür. Muhayyel mekân adı kullanarak kendisine toplumu yerme imkânı yaratmıştır. Yazar, eserinde gerçek bir mekâna atıf yaptığında yöre halkından gelecek tepkinin önüne geçmek adına bu şekilde bir sahte ismi kullanma yoluna gider. Taşranın yozlaşmış ahlâkı eleştirileceği vakit, gerçek kasaba isimlerinin kullanılmamasının son dönem anlatılarında görülen belirgin bir örneği de Şahsiyet (Saylak, 2018) dizisidir.

Mine' de dekor olarak seçilen kasaba mekânı olan istasyon binası ve hemen yanındaki istasyon parkı aynı zamanda eserde simgesel bir değer kazanmıştır. İstasyon şehre yani dışarıya açılan bir kapıyı veya kasabaya geri dönüşü imlemektedir. Bunu gösteren en ilgi çekici sahneleri Cumalı, kente miras davalarını takip etmek için giden köylüleri istasyon parkında tren beklerken konuşturarak gösterir. Bu sahnelerde köylüler diyalekt ile konuşturularak tipik bir Bałı Ege kasabası atmosferi yaratılmaktadır. Tren istasyonu kasabanın en canlı kısmıdır. Kasabanın ve istasyonun en hareketli saatleriyse trenlerin geliş zamanlarıdır. Aynı zamanda gelen trenleri izlemeyi eğlence addeden kasabalı erkekler, aslında istasyona gelerek istasyonun üst katında bulunan lojmanda oturan istasyon şefinin karısı Mine'yi seyretmeyi arzu ederler.

Oyunun ekseninde yer alan Mine karakteri, güzelliğiyle kasabanın bütün erkeklerinin diline düşmüş, hepsinin hayalinde ulaşmayı arzu ettikleri ve bu yüzden 


\section{arts}

çeşitli vesilelerle ona musallat olduklarl; evliliğinde mutluluğu ve gerçek aşkı bulamamış bir kadın portresi çizmektedir. Kasabanın yerlisi erkekler de kasabaya memur olarak dışarıdan gelen erkekler de Mine'ye tutkundur. Kasabanın arzu nesnesi olan Mine, gerçek aşkı kasabaya dışarıdan gelen aydın ve yazar kimliğiyle belirginleşen Illhan'da bulacaktır.

Mine için kasaba erkeklerinin taciz, baskı ve yıldırmalarından kurtulmak için kapandığı evi adeta bir hapishaneyi simgelemektedir. Hapis hayatından farksız olan kasabadan kurtuluş ilhan'la İstanbul'a gitmektir. Necati Cumalı, oyunlarında kadın karakterlerini içinde bulundukları durumu değiştirmek arzusunda betimlerken bunu yaşadıkları mekânı değiştirmek isteğiyle gösterecektir. Yaşanılan yerden gitme veya kaçma arzusu, başka bir yerde farklı bir hayat yaşama arzusu, kadının bulunduğu hâlden memnuniyetsizliğine bulunabilecek tek çare olarak görünür. Cumalı'nın Iş̧ Karar Vermekte, Yeni Çıkan Şarkılar ya da Juliette, Derya Gülü ve Mine oyunları örneğinde görüleceği gibi hem kentte hem taşrada temsil edilen kadınlarda bu durum görülmektedir.

Necati Cumalı, dört yaşından itibaren Urla'da büyümüş ve Ege kasabalarını yakından tanıyarak yetişmiştir. Bunun için onun eserlerinde sunulan Ege kasabası hayatından kesitler, gerçeklikleri dolayısıyla video kaydı kadar değerlidir. Batı Anadolu taşra hayatı, oyunlarda mekânın Urla ve dolayları olarak işaret edilmesiyle işlenmektedir. Tüm eserlerinde kasaba anlatıırken bir noktada kastedilen Urla' dır. Bu da Cumalı'nın çocukluğunun Urla'sıdır. "Coğrafyası, doğal yapısı, insanların özünde var olduğuna inandığı insancıl cevher" (Taş, 2001, s. 14) dolayısıyla Urla'nın değerini teslim eden Cumalı, bu yüzden hemen hemen birçok oyununun mekânını Urla ve dolayları olarak belirtmektedir.

1940' ların sonu Türkiye' sinde, Urla dolaylarında geçen olaylarda köyün yazgısı olarak sunulan susuzluk dolayısıyla kuraklık ve ekilecek toprağın olmaması Susuz Yaz (1964) eserinde hikâye edilir. Bu hikâye, Cumalı'nın aynı adlı öyküsünde de işlenir ve oyun hâline de getirilir. Yine Türk sinemasının şöhretli filmlerinden biri olan Susuz Yaz' a (Erksan, 1963) uyarlanmıştır.

Eserin girişindeki prolog kısmında oyun karakterleri tarafından topluca okunan 
şiirde, oyunda işlenen meseleler adeta özetlenmektedir: "Boydan boya yüz adım atınca/ Tükenirdi bütün toprağımız [...] Meşeleri bodur, ardıçları sıska, ahlatları cılız [...] Nasibimiz kısmetimiz bir karış toprak [...] Kim bizi bu yabanın bayıında unuttu?" (Cumalı, 2004a, s. 551-552). Topraklarının azlığından, verimsizliğinden yakınan halk, dağlara taşlara baktığında gördükleri verimli tabiat manzaraları karşııında dertlerinin susuzluk olduğunu anlar. Bunu prolog bölümündeki şu şiirle ifade ederler: "Ayan oldu bize dilsiz yabanda saklı sır/ Anladık meşeler neden bodur ahlatlar neden kısır/ Anladık dağ taş boğuşur, nedeni su!/ Ardıcı ağlatan su, çamı güldüren su!" (Cumalı, 2004a, s. 552).

Su sorunu etrafında gelişen ve işlenen diğer mühim meselelerle katmanlaşan oyunun olay örgüsü, aynı damda, eserde "Kocabaşların damı" olarak adlandırılan evde yan yana iki göz odada yaşayan iki erkek kardeş ve bir gelin etrafında şekillenir. Bu odaların yan yana olmasının oyun kurgusunda mühim bir rolü vardır. Çünkü evli kardeşinin karısıyla olan yakınlığına onlara kulak kabartarak şahit olan Hasan, böylece hırsına ve arzusuna yenik düşerek oyundaki olayları kendi istekleri ve zaafları doğrultusunda yönetecektir.

Evin bahçesinde kurulan oyun dekorunun ehemmiyetiyse su sorunu üzerinden ortaya konur. Bahçeye yeni yapılan havuz, Hasan'ın hırsla gerçekleştirmek istediği planlar uğruna diğer köy halkını sudan mahrum bırakması ve bütün suyu kendisi için toplamasını göstermek içindir. Amacı "Kocabaşların damını" "Kocabaşların çiftliği" hâline getirmektir. Bu hırsını da şu sözleriyle açığa vurur: "Şeftaliler, kayısılar, zeytin aşılarımız hele bir yetişsin, gün aşırı, İzmir'e, hana bir araba kayısı yıkalım bir gör. [...] Benim bahçe satılık, yabancıya gitmesin, sen almaz mısın diyenleri, yalvaranları.." (Cumalı, 2004a, s. 555). Burada görüleceği üzere Hasan'ın hırsı olayların gidişatını ve eserdeki trajediyi yaratan unsur olacaktır. Ancak oyun sonunda yaptıklarının kefaretini ödeyerek canından olan Hasan, adeta başkalarına zarar veren hırsının kurbanı olacak ve böylece eserde adalet tesis edilecektir.

Yine İzmir dolaylarında bir köyde geçen Vur Emri (1966) adlı oyunda işlendiği üzere kente tutunma çabalarında başarısı olan, uyuşturucu işine bulaştığı için mahkûm edilen Halil, hapiste iken ailesinin onu yalnız bırakması nedeniyle köyüne geri dönerek ailesinden hesap sorar. Oyun, olayların bu noktasında, İzmir yakınlarında bir 


\section{arts}

köy evinin avlusunda geçmektedir. Bir bekçinin silahını alıp kaçması nedeniyle Halil hakkında "vur emri" çıkarımıştır ki eser adını bu hadiseden almaktadır.

Halil on beş yaşında iken yaşadığı köyün gerçeklerine vakıf olmuş ve kendince çıkar yolu büyük kente giderek çalışmakta bulmuştur. Cumalı'nın birçok eserinde görebileceğimiz gibi burada da köydeki topraksızlık ve geçim derdi, Halil'i harekete geçiren unsur olmuştur. Şu sözlerinden onun karar verme sürecinde ailesini ve kardeşlerini düşünen sağlam karakterli biri olduğunu görmek mümkündür: "Sonu yoktu! Neyimiz var dedim? Sonumuz ne dedim? On dönüm tarla. Aklım kestiği zaman gördüm, ne eksek, ne yetiştirsek borcumuza, faizine yetmezdi. Giderim, şehirde iş tutarım, tarlanın üstünden bir boğaz eksilir dedim. Toprakta gözüm yoktu, kardeşlerimi doyursun dedim." (Cumalı, 2004a, s. 723).

Çözümü şehre giderek çalışmakta bulan Halil, bu kararında kendisini çağıran bir "sesin" etkili olduğunu söyler. O sesin İmir'den kendisini çağıran; gaipten gelen bir ses olduğunu belirtir: "Insan içinde o sesi bir kere duymasın. Evden çıkardım, ayaklarım köyün bayıına doğru giderdi. Bayıra varırdım, o ses, bu sefer aşağıda şosadan gelirdi. Şosanın kıyısına inerdim. O ses daha da uzaktan gel derdi. Şosanın, İzmir'e doğru, palamutluklar arasında kaybolan inişine çağıırdı beni.. Şosadan geçen kamyonlar, otobüsler rüyama girerdi. Aklımda ne toprak, ne tarla vardı. [...] Bir gün o sesin çağırmasına dayanamadım, karşı duramadım, koşa koşa gittim..." (Cumall, 2004a, s. 723-724). Böyle bir vesileyle kente gidip çalışan Halil'in hayatı özelinde oyun, 60'lar Türkiye'sinde köyden kente göç etmiş bir gencin başından geçen dramatik hadiseleri karakterlerin diyaloglarıyla yansıtmaktadır.

Yine 1969 yılında yazılmış olan Ezik Otlar, 60'lı yılların Urla'sında otlak kavgasıyla ayyuka çıkan; kendilerini yörenin yerlisi olarak gören kişilerle Urla'ya Karadeniz' den taşınan bir aile arasındaki çatışmaları konu etmektedir. Eserde, otlak kavgasında iki taraf da zarar görür, bir taraf yakınını kaybederken diğer tarafın yakını hapse düşer. Bu klasik hikâye üzerine kurulu oyunda meselenin derinleşmesine neden olan dışarlık olarak görülen Karadenizli ailenin oğluyla kasabanın yerlisi bir ailenin kızının aşkından halkın memnun olmamasıdır.

Toprak kıtlığını bu oyununda da işleyen Cumalı, yöreye dışarıdan gelen 
aileyi olayların merkezine yerleştirerek bölgecilik fikrinin de zararlarını sergilemiş olur. Esasında bu bölgecilik de kendiliğinden değil bir toprak meselesi dolayısıyla öne çıkmaktadır. Kan davası nedeniyle Karadeniz'i terk edip Ege'ye göç eden ailenin satın aldığı otlak, çatışmanın merkezinde yer alır. Yerli aileler, hayvanlarını bakacak otlakları ellerinden alındığından rahatsızlık duyar: "Otlak onların eline geçti geçeli konu komşunun düzeni bozuldu! Kimsenin sağmalını bineğini yayacak yeri kalmadı." (Cumall, 2004a, s. 831).

Düzeni bozduğu düşünülen, halkın kendisine ait olduğunu düşündüğü topraktan onu mahrum eden ve menfaatlerini zedeleyen Laz aileye karşı halk, öfke duyar ve yaşadıkları yöreyi sahiplenen bir söylem geliştirir: "Biz bu yerlerin köklüsüyüz!. Lazlar on yıl olmadı Karadeniz' den geleli, buraların otlağına, bağına sahip çıktılar! Ağabeyin bu ovanın erkeği! Kendine yaraşan yeri, yabancı elinde görmeyi nefsine yedirir mi?" (Cumalı, 2004a, s. 831). İşte satın alınarak sahiplenilen bu çayır, daha önceden köy sandığına kirada olduğundan bütün halk otlak sıkıntısı çekmeden bu çayırdan yararlanabilmektedir. Asıl sorun Karadenizli ailenin bu çayırın mülkiyet hakkını alması ve diğer halkın istifadesine kapatmasıyla gerçekleşir. Aradaki çatışma, klasik bir hikâye olan bir tarafın hayvanlarının otlarken karşı tarafın arazisini ihlal etmeleriyle çıkmışıı. Toprak sorununa dayandırıan bu eserde de karakterlerin bir kurtuluş yolu olarak kente gitme arzuları öne çıkarılmaktadır.

Cumalı, taşranın farklı bir cephesini bir deniz kasabasında geçen Derya Gülü oyununda sergiler. Derya Gülü' nün deniz kenarında geçen sahnesini Van Gogh'un bir tablosundan esinlenerek zihninde kurmuştur. Yazar, ressamın tablosuyla zihnindeki Urla ve İzmir kıyılarına dair anıları birleştirmiş ve eserine zemin oluşturmuştur (Taş, 2001, s. 83-84). Eserini "sevdiğim Urla, genel olarak Ege kıyılarına, o bölgenin gönlü zengin insanlarına selamımdır" diyerek Ege halkına ithaf eden Cumalı, oyunda da yaşamı denizle iç içe olan, deniz sayesinde hayatlarını devam ettiren insanların durumunu gözler önüne sermektedir. Oyunda Meryem, Bodrum' da yaşarken Haşim Kaptan ile evlenip İzmir Körfezi' nin güney kıyılarına Kilizman adı verilen Güzelbahçe civarındaki balıkçı kulübesine yerleşmiştir.

Taşranın ve denizin birlikte göründüğü oyunda, kıyıdaki sahil köşklerinin yanında bulunan balıkçı kulübesinde görünen sefalet sergilenmektedir. Burada yine 


\section{arts}

yaşadığı hayattan kurtulmaya çalışan kadın, gündelik temizliğe gittiği kıyı boyunca uzanan her gün gördüğü köşklere bakarak kurtuluşu umut etmektedir. Bu atmosferde sergilenen oyunda, üç oyun kişisi arasında geçen konuşmalarla eserdeki gerilim sağlanmaktadır.

Ege coğrafyasından kadrajını biraz daha doğuya kaydırıp Güney Anadolu insanının hayatına dair gerçekleri eserine konu eden Cumalı, bu kez diğer eserlerinden farklı olarak insanların hayatına folklorik malzemenin ve halk kültürüne ait efsaneler, halk türküleri gibi ürünlerin çerçevesinden bakacaktır. Özellikle Boş Beşik ve Yaralı Geyik piyesleri bu formda üretilmiştir. Ege coğrafyasına ait sahneleri ustalıkla ve çıplak gerçeklikleriyle eserinde sergileyen Cumalı, Güney Anadolu coğrafyasında geçen piyeslerinde böylece diğer eserlerinden daha farklı bir ton tutturmuştur. Kasabadan farklı olarak köyü konu edinen oyunlarında öne çıkan nokta, folklor malzemesine yaslanarak kurulan efsanevî bir köy imajının sergilenmesidir. Folklorik değeri yadsınamayacak kadar güçlü olan Boş Beşik oyunu, Güney Anadolu'daki bir Yörük obasında yaşananlara odaklanır. Çiçek dağı eteklerinde geçen olaylarda oba ve ova karşıtığını, ovadan gelen ve oba beyiyle evlenen kadının, obalılarla olan ilişkilerinden ve obalıların ona karşı tutumundan gözlemlemek mümkündür.

Boş Beşik'te dramatik unsuru yaratan ölümler, eser boyunca Çiçek Dağı'na verilen kurban olarak sembolleştirilir. Bebeğin kuzgunlar tarafından parçalanması, annesinin aklını yitirip akkuş olduğuna inandığı bebeği ardından atladığı çayda boğulması doğayla insan arasındaki mücadeleyi somutlaştırmakta ve insanın doğa şartları karşısındaki acizliğini ortaya koymaktadır. Sıkça dile getirildiği üzere Çiçek dağı, her yıl bir kurban istemektedir. Bununla ilgili olarak Yörük halkı içinde bir inanış hâkimdir ve bu inanış şu şekilde dile getirilmektedir: "Çiçek Dağı her yıl bir kurban alır, almayınca da bel vermez." (Cumalı, 2004a, s. 45).

Yörük obasındaki çadır hayatı, töre baskısından kaçan oba beyinin av sahneleri, dere ve su kaynakları kenarında geçen olaylar, olağan mevsimlik göç nedeniyle değiştirilen mekân, dağ etekleri, orman gibi geniş bir coğrafî alana yayılan oyun mekânı, tiyatro sahnesinde temsil edilmesi ve tiyatro dekoruna dönüştürülmesi son derece güç bir ortam sunmaktadır. Bununla beraber yazar, oyun metninde dekoru tasvir ettiği yerlerde, anlattığı yörenin topoğrafyasına uygun şekilde sahneyi 
yükseklik ve alçaklığına göre üçe bölmüştür. Dere, Yörük beyinin çadırı, orman, Çiçek Dağı'ndaki geçit sahne içinde bölünerek yansıtıır. Toprak, su, güneş gibi doğaya ait unsurlar da sahnede renkli materyaller ve ışık oyunlarılya temsil edilmektedir. Böyle olmakla beraber, yazarın ilk oyunu olması dolayısıyla oyun mekânı konusunda daha cesur davranıp geniş bir mekân tercih ettiği ve bu konuda sonraki eserlerinde daha ustaca davrandığı söylenebilir.

Cumalı, BoşBeşik'ten otuzyıl sonra 1980' de yine bir halk baladından "Alageyik" efsanesinden esinlenerek yazdığı Yaralı Geyik'i pastoral oyun olarak niteler. Hayattaki başlıca gayesi av olan, hayatın anlamını doğa içinde avlanırken bulan Duran Sarıca, daha oyunun başında yaşadığı kasabadan avlanmak için ayrılan ve kırk gündür dağlarda bulunan bir karakter olarak okura/seyirciye gösterilmektedir. Kendi varlığını doğa içinde tanımlayan Duran Sarıca, bunu "Bu dağlar ikimizin. Koca geyikle benim! Bir gün yalnız benim olacak.." (Cumalı, 2004b, s. 306) sözleriyle ifade eder.

Iki bölüm ve toplamda on altı sahne olarak kurgulanan oyunun ikinci bölümü, hayvanların konuşturulması suretiyle fabl türüne yaklaşıp alegorik bir tona bürünürken insanın doğadaki diğer canlılarla olan münasebetini sergilemektedir. Pastoral bir oyun olarak Yaralı Geyik, özellikle ikinci bölümde dağ yolu ve ormanlık alanda geçen sahneleri, beşinci sahneyi içeren "Ormanda Uyku" bölümüyle öne çıkmaktadır.

Köy anlatılarında yaygın olarak görülen bir motif olan, kendisine âşık olan ayı tarafından kaçırılan ve ayı ininde zapt edilen bir kadın bu oyunda da yer alır. Kasabada bu ayının hakkından gelebilen tek kişi olan Duran Bey, bu yüzden kasabanın en güçlü ve halk tarafından kendilerine liderlik etmesi arzulanan kişisi hâline gelir. Ancak hiçbir zaman kendisini kasaba hayatı içinde mutlu görmeyen, koca geyiğe sahip olmak uğruna kendini dağlara ve doğanın kucağına bırakmak isteyen daha doğrusu doğaya hükmetmek isteyen Duran Sarıca, bu uğurda kasabalıların kendisine sunduğu imkânları, kasabanın başkanı olma teklifini, sevdiği kadına kavuşma imkânını geri teper. Hatta bu sevdası uğruna canından olacaktır.

Kasaba hayatını sergileyen oyunlardan biri olan Yaralı Geyik'te, oyunun 


\section{arts}

zaman kurgusu dolayısıyla kasaba hayatındaki dönüşümden de bahsedilmektedir. Eserin ikinci bölümünde yirmi yıl sonrasından başlatılan olaylarla kasaba hayatının dönüşümü oyunda sergilenen nesnelerle gösterilir. İlk bölümün başında dekor olarak tasvir edilen saraç dükkânı ikinci bölümün de ilk sahnesine dekor olmaktadır. Dükkânda üretilen malların türleri yirmi yılda değişmiştir: Koşum takımları, at başlıkları yerini deri kemerlere, mavi boncuklu deri kolyelere, askılı çantalar ve yazlık sandallara bırakmıştır. Böylece eserde zaman ve mekânın dönüşümü üretilen eşyaların gösterilmesiyle bir arada verilmiş olur.

Daha önce Susuz Yaz eserinde suyun taşra yaşamındaki önemine değinen Cumalı, bu kez Kuyu adlı eserinin mekânını Güney Anadolu'ya çevirerek meseleyi Anadolu'nun farklı bir coğrafyası içinde ele alır. Bu kez mekân Hatay'ın ismi yazar tarafından değiştirilen bir köyüdür ve seksenler Türkiye'sidir. Bir yasla açılan oyunun Almanya'dan dönen kahramanı Ceyhan Atik, ölen annesinin hayrına memleketini suya kavuşturmak ister. Yazarı tarafından bililtizam Kuruoba olarak adlandırılan bu köy, kuraklıkla boğuşan ve bereketsiz topraklar olarak ad dedilebilecek bir coğrafyayı temsil etmektedir. İki katlı bir köy evi ve bahçesinde bulunan kuyu açma alanı oyuna dekor olarak belirlenmiştir. Motorlu araçların, radyonun, köydeki köpeklerin vesairenin seslerini oyununa ekleyen Cumalı, böylece dekor olan köy evinin etrafında yaşanan köy hayatını canlı bir şekilde seyirciye aktarmaya çalışmaktadır.

Eserin ilerleyen bölümlerinde de göreceğimiz gibi coğrafyanın kaderini başta köy muhtarı olmak üzere idari ve bürokratik yapı şekillendirir. Su bulma, kuyu açma mücadelesinde Ceyhan Atik'in önüne çıkan tüm engeller, siyasi büyüklerine sırtına dayadığını düşünen muhtarın elinden gerçekleşir. Eserde ayrıca üstünde durulmayı hak eden bir husus, kadınların meseledeki rolüdür ki Ceyhan Atik'in köyü suya kavuşturma sürecinde kendisine en çok destek veren ve yardım eden kişiler çevresindeki kadınlar olur. Geçim derdi ve diğer sebepler nedeniyle kuyu açma sürecinde yanından ayrılan erkeklere rağmen Ceyhan Atik'in etrafında, akıllı ve muhtarın hilelerini bozan bir kadın olarak öne çıkan Zühre başta olmak üzere kadınlar bulunmaktadır. 


\section{arts $=$}

\section{Komedi Türü İçinde Temsil Edilen Taşra}

Necati Cumalı'nın oyunlarında komedi türü içinde temsil edilen taşraya baktığımızda hem insanlara hem siyasi çevrelere hem de toplumun ahlâk anlayışı ve geleneklerine eleştirel bir tutumla yaklaşıldığı; hicve yakın bir güldürü anlayışının hâkim olduğunu görmekteyiz.

Menfaat temasının büyük bir ustalıkla işlendiği 1953 ylında yazılmış Kristof Kolomb'un Yumurtası adlı oyun, toplumsal yergi ve taşlamanın özgün bir örneğidir. Bir avukatlık bürosunda geçen ve etrafta bu büroyu oluşturacak nesnelerle kurulan dekor içinde sergilenen oyun, kasabadan İzmir'e miras davasını görüşmek için gelen Kemalpaşalı bir bakkalın hak arayışını hikâye eder. Saf ve temiz taşra insanı bakkal ile kentli kurnaz turizmci ve avukatın konuşturulduğu sahneler, zihniyet farkı ve eğitim düzeyi bakımından iki yerleşim yerinin kasabanın ve kentin hâlini canlı bir şekilde göstermektedir.

Boş Beşik ve Yaralı Geyik gibi yazarın folklorik yönüyle öne çıkan oyunlarından bir diğeri de, yazarı tarafından fars türü içinde nitelendirilen, Cumalı'nın erken yazarlık dönemi ürünlerinden olan tek perdelik kısa oyundur. 1954'te yazılmış Kaynana Ciğeri adlı bu oyun, düğünlerde oyun havası şeklinde söylenen bir halk türküsünden esinlenilerek yazılmıştır. Cumalı, bu eserine kaynaklık eden düşüncelerini "Oyunlarımızda Folklorun Rolü" başlıklı yazısında açıklarken gittiği düğünlerde dinlediği oyun havalarını tiyatro şeklinde düşündüğünü belirtir. Esasen bu oyun da bu fikrin bir ürünü olarak ortaya çıkmıştır (Taş, 2001, s. 71). Necati Cumalı'nın oyun yazarlığı içinde önemli bir yeri olduğunu söyleyemeyeceğimiz oyun, bir köy evi dekorunda sergilenmekle beraber törelerimizde kadının ne kadar değersiz olduğunu göstermektedir.

Kız kaçırma hadisesinin töre komedyası şekliyle işlendiği Nalınlar (1960) adlı eser, Cumalı'nın oyun yazarlığında mühim bir yer elde etmiştir. Urla dolaylarında geçen bu oyunda, karakterlerin sayısı ve olayların geçtiği mekân kısıtlıdır. Döndü'nün, Muhtar'ın ve Akkuzuluların evlerinin avlu duvarları ayrı birer paravanla gösterilir. Bunun dışında köy meydanı ve çeşme başı gibi halkın karşılaştığı alanlar oyuna dekor yapılır. Bu dar dekora karşın sahnede kullanılan nesneler ve bazı nesnelerin çıkardığı 


\section{arts}

sesler oyun içinde büyük bir ehemmiyet kazanır ve sahnede nesnelerin dizilimi veya diğer şekillerde kullanılmasıyla kurulan bir sembolik anlatım şekli sergilenir.

Gömü (1971) adlı oyunda ise insanların fal merakı ve para hırsı nedeniyle düştükleri gülünç durumlar sergilenir. Urla'da geçen olaylarda, bir mübadilin Atina'dan gelen mektubunda bahsettiği gömü hikâyesi olayların gidişatını belirler. Kasabanın eski sakinlerinden Hristo, kâtibi Yani'nin evinin bahçesindeki gömüden bahseder mektubunda. Oyunda "Ben Urla' nın canlı topoğrafyasıyım", "Letafet Abla canlı nüfus kütüğü" (Cumalı, 2004b, s. 70) diyen Arif ve Letafet'in hatırladıklarıyla gömünün hangi evde olduğu belirlenir. Sıdıka Beyaz'ın evinde geçen fal bakma sahnesiyle başlayan oyun, bu evin bahçesinde yapılan gömü bulma kazılarıla sürmektedir. Bu doğrultuda oyunda taşra insanının zaafları ve açgözlülüğü komedi üslubunun konforu içinde eleştirilerek sergilenmiş olur.

Köy ve kasabanın sorunlarını komedi türüyle anlatan Necati Cumalı, bu oyunlarında taşranın kenarda bırakılmış hâlini, merkez ve özellikle hükümet tarafından ötelenmiş olduğunu gözler önüne sermek ister. Bilhassa Bakanı Bekliyoruz (1972) adlı oyununda bu öne çıkar. Bu eserde olaylar 50'li yıllarda Urla Sağlık Merkezinde geçmektedir. Kasaba hastanesini teftişe gelmesi beklenen bakanı, hastane çalışanları büyük bir kaygıyla beklemektedir. Hastanenin yalnızca bir hastası bulunduğu için kurumlarını hükümete atıl kalmış göstermemek adına sahte hastaları hastaneye yatııılar. Hastane çalışanları, kasabanın kaymakamı ve diğer ileri gelenlerinin bu bekleyişine karşın bakan Urla'ya uğramadan tüm gününü Çeşme plajlarında keyif çatarak geçirir. Tüm bu olaylar bir noktada hükümetin ve devletin ileri gelenlerinin taşraya karşı takındıkları umursamaz ve onları görmezden gelen, kenarda bırakan tavırlarını ortaya koymaktadır.

\section{KENT VE KÜÇÜK INSSANIN GÜNDELIK DERTLERI: ISTANBUL, ANKARA VE İMIR}

Taşra Anadolu'suna böyle bir perspektiften bakan Necati Cumalı, 1955 yllında yazdığı Iş Karar Vermekte adlı oyundan itibaren özellikle İstanbul ve Ankara'da geçen çeşitli oyunları aracılığıyla kent içinde yaşamını sürdüren insanların hayatına odaklanmıştır. Iş Karar Vermekte'yle birlikte Masalar (1966), Yeni Çıkan Şarkılar yahut Juliette (1966), Ahmetlerim (1970), Yürüyen Geceyi Dinle (1974), Şafak Karakolu 
(1979), Bir Sabah Gülerek Uyan (1980), Dün Neredeydiniz? (1981), Devetabanı (1983), Gel Evlenelim, Yürü Boşanalım (1984), Yalnız Ölü (1990) kentli insanın yaşamını anlatan eserlerdir.

Cumalı, taşrayı konu eden eserlerinde ve kente göç, hayatını kazanmak için büyükşehrin yolunu tutma meselelerini işlediği oyunlarda İzmir şehrinin adını anarak oyun çerçevesi içinde bir İzmir kenti imgesi kurmaktadır. Daha önce de değindiğimiz üzere Vur Emri oyununun hükümlü ve sonradan kaçak kahramanı yaşadığı kasabayı imkânsızlık nedeniyle terk ederek İmir'e gider. Yine Ege taşrasında yaşayan oyun karakterleri hukuki işlemleri veya devlet dairesindeki işleri nedeniyle İzmir kentinin yolunu tutar. İzmir, sağladığı kolaylıklar ve imkânlar nedeniyle taşra insanının zihninde hayallerini süsleyen ve umut vadeden bir mekân olarak büyük kent imajını kazanmaktadır.

Bununla beraber yazarın Ankara ve İstanbul arasında geçen ve kentte yaşanan hayata odaklanan ilk eseri 1955 yılında yazılan Iş Karar Vermekte adlı oyundur. Bu oyunda kentli insanın buhranları ve farklı hayat yaşama arzuları, bulundukları kenti terk etmek şeklinde tezahür etmektedir. Illk bölümde Ankara'yı terk ederek aşkı nedeniyle kendisine yeni bir hayat kurmak için İstanbul'a giden kadının yolculuğu işlenirken; oyunun ikinci bölümünde yaşadığı pişmanlık sergilenmektedir. Bu pişmanlık Ankara'ya duyulan özlemin ifade edilmesiyle yansıtılmaktadır.

Oyunda İstanbul tüm semtleriyle önce hayali, sonra da hayal kırıklığını temsil etmekte; Ankara ise güzel anılarla ve özlemle birlikte anılmaktadır. İstanbul'a gitmeye kararlı bir şekilde Ankara garında bekleyen Oya, İstanbul'un mekânlarına Balıkpazarı, Çamlıca, Adalar ve hatta Loti' nin Azade'sinin mezarına gitmek arzusunu belirterek bu kente dair romantik düşlerini ifade etmektedir. Bunu yaparken de Pierre Loti'nin romantik İstanbul imajıyla hayallerini şekillendirmektedir. Ankara'dan ayrıma isteğini körükleyen sevgilisinin ardından gitmek ve onunla beraber anılar biriktirdiği Ankara semtlerinden uzaklaşmak arzusudur. Bunu da "Keşke Kavaklıdere, Çiftlik, Dikmen seninle nerelere gitmişsek hiçbiri olmasaydı dedim..." (Cumalı, 2004a, s. 121 ) sözleriyle belirtir.

Buna karşın İstanbul'da Doğan'la arzu ettiği hayatı kuramadığı noktada 


\section{$\operatorname{arts}=$}

Ankara düşleri belirecektir. Çünkü hayalleri alabildiğine İstanbul'un güzellikleriyle dolu olan Oya, geçim derdi ve parasızık nedeniyle sevgilisi Doğan'ın arkadaşının bir göz odalı evine sığıntı gibi hapis olmuştur: "Ankara şimdi ne güzeldir... [...] Bayılıım Ankara'nın sonbaharına. Sıhhiye'ye giderken otobüs garajının parmaklıklarından sarkan o yabani sarmaşıklar var ya? Şimdi hafif bakıra çalmıştır. Baylııım onların rengine..." (Cumalı, 2004a, s. 132).

Yazarın İstanbul ve Ankara'da geçen oyunlarına baktığımızda dikkat çeken öğelerden birisi devlet dairelerinin nasıl temsil edildiğidir. Özellikle Masalar, Şafak Karakolu ve Gel Evlenelim, Yürü Boşanalım isimli oyunlarında komedi türü içinde devlet dairelerine ve devlet kurumlarına ironik ve eleştirel bir tonda yaklaşıldığı görülmektedir.

Masalar (1966), politik eleştiri tonu ağır basan bir komedidir. Liyakatin değersizleştirilmesinin, adam kayırmanın ve nepotizmin eleştirildiği oyunda, olaylar devlet dairesi dekoruiçindesunulur. Adı anılmayan birbakanlığın yayın müdürlüğünde yan yana iki ofiste geçer oyun. Burada esere adını veren ofis içindeki masalar ve bu masaların sürekli yer değiştirmesi, devlet dairesindeki idare ve çalışma düzenindeki değişiklikleri simgelemektedir. Gözden düşen bir memurun masası ivedilikle odanın en çirkin yerine atılır ve kendisine hiçbir şekilde itibar gösterilmez. Buna karşın yüksek yerlerde tanıdıkları olan, "Ankara'da dayısı veya amcası bulunan" memurlar itibar görür ve masası en iyi yere konur. Bu nedenle devlet dairesinde yaşananlar ve sürekli yeri değişen masalar, ülkenin geneline yayılmış politik düzene ve memuriye† anlayışına işaret etmektedir.

Yazarın bir başka devlet kurumu olan mahalle karakollarını oyununa mekân olarak seçtiği eser, Şafak Karakolu'dur (1979). Bu oyun, aynı zamanda mahalle imgesi etrafında şekillendirilmesi itibariyle özel bir örnektir. Burada İstanbul'un uç semtlerinden birinde yeni kurulmuş olan bir mahalleden bahsedilir. Bu mahalle, tenhalığı ve devlet denetiminden uzak olmasl; mahallede hiçbir resmî kurumun bulunmaması sebebiyle dikkat çekmektedir. Bu sebeple oyundaki karakterler, devletten habersiz Şafak Mahallesi'ne bir karakol kurmaya karar verir. Beyoğlu'nda Tepebaşı'na çıkan ara sokaklardan birinde köhne bir lokantada başlayan oyun, İstanbul'un yeni kurulan bir mahallesinde devletten habersiz açılan bir polis 
karakolunda devam edecektir. Lokantanın işletmecisi olan kadının ve etrafındaki "aynasız takımının" yeni karakolun komiseri ve memuru yapılmasıyla, eserdeki ironik tonun yakalanması hedeflenmektedir.

Merkezden uzak, hemen hiçbir devlet dairesinin bulunmadığı bu mahallede açılan Şafak Karakolu, memur ve idarecilerinin kendine has adalet anlayışıyla mahallenin huzur ve güvenliğini tesis eder. Kent içindeki kaçakçılığın ve karaborsanın merkezi, anarşinin kaynağı olarak görülen mahallede dünyanın ilk halk karakolunu açmayı düşünen aynasız takımı; yakaladığı suçluların silahlarına el koymakta ve bu silahları mahalle güvenliğini sağlamak için imzayla ve yoklamaya getirmeleri şartıyla dürüst insanlara dağıtmaktadır. Devletten habersiz ve illegal olarak kurulan bu karakolun işleyişinin mahalle halkını memnun etmesi ve mahallelinin talebiyle karakol çalışanlarına takdirname ve ikramiye maaş verilmesi de yine ironiyi kurma maksadıyla kurmacaya yerleştirilmiş detaylardır.

Gel Evlenelim, Yürü Boşanalım (1984) adlı oyunu da nikâh dairesi ve boşanma davasının görüldüğü mahkeme salonunda geçmesi itibariyle devleł dairelerinde geçen diğer oyunlarla beraber değerlendirebiliriz. Yalnızca bu oyunda, eserin "evlenme konusu üstüne fantezi oyun" olarak nitelendirilmesi nedeniyle mekânların fantastiğe uygun şekilde oluşturulduğu ve tasvir edildiği görülmektedir. Oyun mekânı, olağanüstü öğeler ile belirginleştirilmektedir. Nikâh dairesinin bu yönüne dikkat çeken oyun kahramanının da belirttiği gibi nikâh dairesi, evlilik kurumu hakkındaki zihniyet ve fikirlere göre mimarı tarafından hususi olarak tasarlanmıştır.

\begin{abstract}
Mimarın odaya bu biçimi vermesinin bir anlamı olduğunu düşünmek hiç aklınıza gelmiyor mu? [...] Mimarın, bu odaya bu biçimi vermeden önce, değişik medeni kanunların aile hukuku ile ilgili bütün hükümlerini, evliliğin tarih boyunca değişik toplumlarda geçirdiği ekonomik, toplumsal, ruhsal, cinsel [...] siyasal! Tüm evrelerini titizlikle incelediği, güvenilir uzmanların onayından geçerek kesinleşmiş bir değerlendirmedir. Bu oda, dış görünümüyle evliliğin yapısal kuruluşunu simgeler. Evlenecekleri nikâh memurunun önüne çıkmadan önce, son bir kez nasıl bir yükümlülük altına gireceklerini düşünmeye çağırır! (Cumalı, 2004b, 745-746).
\end{abstract}

Yazarın oyununda böyle bir fikri ortaya atması, mekânın felsefi boyutuyla ele alınması açısından dikkat çeken bir örnektir ve eseri bu noktadan değerli kılmaktadır. Oyunun son bölümünde boşanma sahnesinin sergilendiği mahkeme salonu da tıpkı 


\section{arts}

ilk bölümdeki nikâh salonu gibi kendine has özellikleriyle fantezi oyun kurgusuna uygun bir surette şekillendirilmiş ve tasvir edilmiştir.

Kent yaşamında kamusal alana odaklanan eserlerinden sonra yazarın ev içine, özel alana odaklanan eserlerine baktığımızda, mekânı ev içiyle sınılamanın karakterler arasındaki ilişkileri daha derin yansıtmak için kullanılan bir yöntem olduğu görülebilmektedir. Aynı zamanda ev içiyle sınırlandırılan oyun, dekora dönüştürülmesi sürecinde de daha büyük rahatlık sağlamaktadır.

Adını Baudelaire'in dizelerinden alan Yürüyen Geceyi Dinle (1974) adlı oyunda, sıkıyönetim altında, eve kapanan insanların hayatı yansıtılmaktadır. Sokağa çıkma yasağı nedeniyle eve kapatılmış insanların ev içindeki sıkışmışlıkları işlenmektedir. 1974 ylında tamamlanan eser, 12 Mart dönemini anlatmaktadır. Eserde temsil değeri kazandırmak adına karakterlere isim verilmemiş ve karakterler "Kadın/Erkek/Komşu/Delikanlı" olarak belirtilmişlerdir.

1971 ylının ilkyazında İstanbul'da orta halli bir aydının evinin salonunda geçtiği belirtilen oyun, silahlı mücadeleye inanan delikanlı ile kalemiyle mücadele etmeyi savunan bir aydının fikir çatışmalarını sergilemektedir. Cumalı, burada "erkek" olarak isimlendirdiği kahramanına söylettikleri ile ele alınan meselelere dair kendi bakış açısını sergilemektedir. Bu anlamda klasik ifade ile aydın yazar kahramanın Cumalı'nın eserdeki sözcüsü olduğunu söylemek mümkündür.

Eserde aynı zamanda aydın kahramanın belirttiği kasaba gerçeği de yazarın fikir dünyasına uygun bir biçimde dillendirilmiştir. Doğup büyüdüğü Anadolu kasabasından bahseden Erkek, bu kasabanın Türkiye'nin küçük bir görüntüsü olduğunu yani her haliyle kasabanın, içinde bulunduğu ülkeyi temsil ettiğini belirtmektedir: "Küçük bir kasabada yaşardık. İnsan sayısı on bini biraz aşardı. Küçük bir kasaba ama, memleketin tümünün özetiydi. Toplumumuzun her kesitinden derlenmiş toparlanmışörneklerdi sanki halkı. Particiler, daha büyük kentlerde yaşayan daha ünlü particilerin kopyasıydı. Tüccarlar daha büyük tüccarların burnundan düşmüştü." (Cumalı, 2004b, s. 246).

Yürüyen Geceyi Dinle oyununda yansıtılan ev içi atmosferini, kadın 
karakterler için yazılmış tek kişilik oyunlarda da farklı cephesiyle görmekteyiz. Özellikle geçmişi anımsayarak veya hayatının mevcut halini ve geleceğini düşünerek bir muhasebe yapan karakterler işleneceği vakit, evin salonu oyunda mekân olarak kullanılmaktadır. Yeni Çıkan Şarkılar yahut Juliette (1966) ve Ahmetlerim (1970) isimli oyunlar bu atmosferde geçmektedir.

Yeni Çıkan Şarkılar yahut Juliette oyununda isimsiz olarak kurgulanan genç kız, yaşadığı evi ve içinde bulunduğu odayı bir sığınak olarak görmektedir. Oyunun başlarında dışarıya, şehirde akıp giden hayata özlem duyuyor gibi görünse de evde olmak onun için önemlidir. Bu anlamda genç kızın ruh hâline kimi zaman dışa açılma arzusu kimi zaman da içine kapandığı evdeki konfordan duyulan memnuniyet hâkimdir: "Ben evimi seviyorum doğrusu! Bu odayı seviyorum! Düzgün, her şey yerli yerinde olursa daha çok seviyorum! (..) Oturur, beklerim! Bir gün ne istediğim, ne aradığımı bulsam bulsam bu odada bulurum... Sokakların caddelerin kalabalığında hep unutuyorum ne aradığımı..." (Cumalı, 2004a, s. 740).

Bu oyunda kapalı mekân içinde duyumsanan dış dünyanın izleri, kente ait seslerin yansıması şeklinde görünmektedir. Genç kız pencereden gözlemlediği manzaralar ve dışarıdan duyduğu sesler ile zihninde kente ait imajlar kurmaktadır. Bu doğrultuda zihninden geçirdikleri monolog halinde eserde sergilenmektedir.

Ev içi hayatı merkeze alan oyunlarda yazarın odaklandığı meselelerden biri de insanların kendi özel alanlarında kendilerine tasallut eden insanlar dolayısıyla yaşanan sıkıntılardır. Bir Sabah Gülerek Uyan (1980), oyununda Ankara Çankaya'da bulunan Suna' nın evi, hem sevgili olmak maksadıyla onu ziyaret eden erkekler hem de onların gönderdikleri çiçekler ile istila edilmektedir. Eserde, kadının isteksizce karşıladığı misafirleri yüzünden özel alanının zapt edilmesi ve böylece kadının hayatının istila edilmesi söz konusudur. Sonunda kadın, kendi hayatını kendi istediği doğrultuda yaşamak adına kendisiyle evlenmek umuduyla yaklaşan bütün erkekleri yalnız yaşadığı evinden uzaklaştıracaktır.

Devetabanı (1983), adlı oyun da benzer bir şekilde insanların kendileri için yarattıkları özel alana tasallut eden kimselerin yaklaşımını eleştirmek adına yazılmıştır. Başkalarının hayatında gereğinden fazla yer kaplayan insanlar için eserde 


\section{arts}

"yayılma hastalığı" gösterdikleri söylenmektedir. Bu yayılma hastalığı "ortak yaşamı dayanılmaz hâle getiren", "karşısındakinin yaşam alanını daraltan" bir durum olarak gösterilmektedir.

Bu durumun simgesi olarak oyunda taşınma hediyesi olarak getirilen devetabanı bitkisi kullanımaktadır. Devetabanı, tıpkı insanın özel yaşam alanında varlığından hoşnut olmadığı kimseler gibi sürekli ve hızlıca büyüyerek daha fazla alan işgal edecek ve zamanla evin en güzel yeri sayılacak kısımlarını istila edecektir. Bu metafora benzer şekilde oyunda illter isimli kahramanın uzun emekler sonucunda elde ettiği Etiler' deki müstakil ve bahçeli bir evde kurduğu konforlu hayatı da yaptığı evlilik dolayısıyla istila edilecektir. Tüm bunları göz önünde bulundurarak bu eserde yazarın, evi simgesel bir değer ile sunduğu ve evin, insanın özgür ve serbest hayatını simgelediğini söylemek mümkündür.

Yazarın 1990 yılında yazdığı son oyunu Yalnız Ölü'dür (1990) ve burada da Devetabanı oyununda olduğu gibi eve, simgesel bir değer atfedildiğini söylemek mümkündür. Kuyu oyunundaki gibi bir ölüm ile açılan oyun, ölen ev sahibinin vasiyeti etrafında şekillenmektedir. Hayatı boyunca çalışıp emek vererek kendine müreffeh bir hayat tesis etmiş olan Kerem Balkan, ölümünden sonra arkadaşlarının ve ev çalışanlarının evdeki mevcut yaşam şeklini devam ettirmelerini vasiyet eder. İçinde yaşanılan hayatın sürdürülmesi ve böylece kendi anısının canlı tutulması arzusuyla, kendisinin varlığının sürmesi ile ev hayatının devamlılığı arasında bağlantı kuracaktır.

\section{SONUÇ}

Necati Cumalı'nın edebiyatımız için önemi, Batı Anadolu kasabalarını roman, öykü, tiyatro, şiir ve deneme gibi birçok edebî türde ustalıkla okuruna ve seyircisine sunmasıdır. Cumalı, oyunlarında köy ve kasabanın farklı yerlerini, hem hastane, istasyon gibi kamusal mekânlarını hem de ev içi özel alanını, köy evlerini, bahçelerini, halkının geçimini sağladıkları toprakları bizlere gösterir. 1940'lardan 1990'lara değin uzanan bir zaman aralığında memleket ahvalini ve Türkiye gerçeğini eserleriyle okuruna gösterir. Onun eserleri yoluyla o dönem toplum hayatına, Anadolu taşrasının hâline şahitlik edilmiş, taşra insanının derdi ve meseleleri görülmüş olur. 
Necati Cumalı, köyü ve taşrayı oyunlarına mekân olarak seçtiği eserlerinde, toprak sorununa ve köylünün kuraklık meselesine değinir; köy halkını kahramanlaştırmadan bütün zaafları ve içgüdüleriyle sergilemektedir. Bu da eserlerindeki gerçekçilik dolayısıyla hem edebiyatımıza hem de diğer sosyal bilimler alanlarındaki tetkiklere mühim katkılar sağlamaktadır. Tıpkı köy gibi kasabayı da aynı gerçekçi üslup ve anlayışla sergileyen Cumalı, kasaba hayatı hakkındaki görüşleri ve fikirleri; eserlerindeki kasaba temsilleri ile adeta bir "kasaba edebiyatçısı" olarak nitelendirilebilmektedir.

Oyun yazarlığının ilk zamanlarında daha çok köy ve kasabayı anlatan Necati Cumalı, sonraki yıllarda özellikle 1970 ve 80'li yıllarda kent hayatına ve kent insanının sorunlarına eğilmiştir. Ankara ve i̇stanbul kentlerinde yaşanan hayata odaklanan bu oyunlarda, hem eserin yazıldığı döneme ait olaylar -bazen çeşitli anlatım teknikleriyle üstü kapalı olarak bazen de açık bir şekilde- anlatılır; hem de evrensel duygu ve meseleler hikâye edilerek işlenir. Kent hayatına odaklanan oyunlarının büyük kısmının ev içi hayatından sahneler sunduğu görülmekle beraber yazar, devlet daireleri ve devlet kurumlarına ait mekânlarda geçen oyunlarında güldürü türünü kullanıp ironik ve yergisel bir üslup benimsemiştir. Bu eserlerde güldürü tonuna uygun düşecek şekilde mekânın da karikatürleştirildiğini söylemek mümkündür. Yazarın oyunlarına kent imgesi etrafında bakılırsa İstanbul, Ankara ve İzmir şehirlerinden en çok İzmir'in temsil değeri taşıyarak bir büyük kent imajına büründüğü düşünülebilir. Çünkü İzmir, oyunlarda sergilenen taşra insanının umudunu besler, hayalini süsler, önüne bütün imkânları sunacak bir anahtar olarak görünmektedir.

\section{KAYNAKÇA}

Aslan Cobutoglu, S. (2014). Ahmet Midhat Efendi'nin Romanlarında Edebiyat Coğrafyası: Karadeniz ve Çevresi. (Yayımlanmamış Doktora Tezi). Marmara Üniversitesi Türkiyat Araştırmaları Enstitüsü, İstanbul.

Brosseau, M. (1994). Geography's Literature. Progress in Human Geography, $18(3), 333-353$.

Brosseau, M. (2009). Literature. International Encyclopedia of Human Geography. (Cilt 6, s. 212-218). Oxford: Elsevier. 


\section{arts}

Cumalı, N. (1949). Boş Beşik. İzmir: Halkevi.

Cumalı, N. (1959). Mine. İstanbul: Varlık.

Cumalı, N. (1963). Derya Gülü. İstanbul: Kent.

Cumalı, N. (1969a). Boş Beşik, Ezik Otlar, Vur Emri. İstanbul: İmbat.

Cumalı, N. (1969b). Susuz Yaz, Tehlikeli Güvercin, Yeni Çıkan Şarkılar. İstanbul: İmbat.

Cumalı, N. (1969c). Nalınlar, Masalar, Kaynana Ciğeri. İstanbul: İmbat.

Cumalı, N. (1973). Gömü, Bakanı Bekliyoruz, Kristof Kolomb'un Yumurtası. İstanbul: İmbat.

Cumalı, N. (1977). Mine, Yürüyen Geceyi Dinle, Iş Karar Vermekte. İstanbul: İmbat.

Cumalı, N. (1980). Yaralı Geyik. İstanbul: Devlet Tiyatrosu.

Cumalı, N. (2004a). Bütün Oyunları: I. İstanbul: Cumhuriyet.

Cumalı, N. (2004b). Bütün Oyunları: Il. İstanbul: Cumhuriyet.

Çam, A. (2016). Sinemasal Mekânlar ve Sinemasal Mekânların Çözümlenmesi. sinecine, 7(2), 7-37.

Çam, A. (2018). Sinemasal Hodolojik Mekânlar-Bir Zamanlar Anadolu'da Filminin Hodolojik Mekân Bağlamında Çözümlenmesi. Yeni Düşünceler, 9, 45-56.

Erksan, M. (1963). Susuz Yaz. [Film]. Türkiye: Hitit.

Günday, H. (Senarist) \& Saylak, O. (Yönetmen). (2018). Tüm Bölümler [Televizyon Dizisi Bölümü]. K., Çatay, P. D., Yaşaroğlu (Yapımcı), şahsiyet. Türkiye: Ay. Kaplan, M. (2014). Nesillerin Ruhu (12. Baskı). İstanbul: Dergâh.

Kavaz, I. (2018, Aralık). Tarık Buğra ve Kasaba Edebiyałı. Türk Dili, 68(804), 147158.

Kefeli, E. (2006). Edebiyat Coğrafyasında Akdeniz. İstanbul: 3F.

Kefeli, E. (2009). Coğrafya Merkezli Okuma. Electronic Turkish Studies, 4, 421433.

Korat, G. (2005, Nisan). Yazar ve Coğrafya. Kitap-lık, 82, 52-55. 
Narlı, M. (2013). Romanlar ve Taşralar: Türk Romanında Taşra Algıları Üzerine Deneme. Bilig, 64, 285-316.

Pocock, D. C. D. (1981). Place and the Novelist. Transactions of the Institute of British Geographers, 6(3), 337-347.

Tally Jr., R. T. (2017). Spatiality. Londra\&New York: Routledge.

Taş, S. (2001). Necati Cumalıv ve Oyunları. Ankara: Kültür Bakanlığı.

Uğurcan, S. (2012). Edebiyatımız II-Yazarlar, Meseleler. İstanbul: Dergâh. 